\title{
Evaluation of Gas Reservoir of the Meghna Gas Field, Bangladesh Using Wireline Log Interpretation
}

\author{
Abu Reza Md. Towfiqul Islam ${ }^{1, *}$, Md. Aminul Islam² \\ ${ }^{1}$ Department of Disaster Management, Begum Rokeya University, Rangpur, 5400, Bangladesh \\ ${ }^{2}$ Department of Petroleum Geoscience, Faculty of Science, Brunei Darussalam University, Gadong, 1410, Brunei \\ *Corresponding Author: gm_towfique_06@yahoo.com
}

Copyright $@ 2014$ Horizon Research Publishing All rights reserved.

\begin{abstract}
The gas reservoir from the well Bakhrabad-09 of the Meghna Gas Field, Bangladesh was evaluated in this study in order to appraise the qualities of the reservoir based on quantitative analysis of petrophysical parameters. Among 24 permeable zones, two zones were gas-bearing and rests were water-bearing zones which identified in the study well. Relatively high resistivity, high SP log, low gamma ray log, very low neutron and low density log responses indicate hydrocarbon type might be gas-bearing zones than that of water-bearing zones. The shale volume of those zones ranged from average $21 \%$ to $22 \%$ indicated that shaly sand dominating lithology and less affect the water saturation values in the gas reservoir. The average porosity of these zones ranged from $31 \%$ to $34 \%$ which was within the limit for good hydrocarbon accumulation. Three saturation equations were used to evaluate the water saturation which was converted to gas saturation. The average gas saturation values of these zones were more than $60 \%$ indicate high hydrocarbon accumulation. The average permeability of these zones ranged from $42.5 \mathrm{md}$ to $50 \mathrm{md}$ respectively which was within ranged for commercial gas accumulation. Average bulk volume of water ranged from 0.045 to 0.053 was shown that the reservoir consist of mainly fine to very fine grained sandstone and more or less at irreducible water state. It can be concluded that gas reservoir are good qualities for commercial hydrocarbon accumulation and production.
\end{abstract}

Keywords Wireline log, Meghna Gas Field, Well Bakhrabad-09, Reservoir quality and Hydrocarbon accumulation

\section{Introduction}

Wireline logs are helped to define physical characteristics of the reservoirs such as porosity saturation, hydrocarbon moveability and permeability [1]. Petrophysical evaluation has a unique opportunity to observe the relationship between porosity and saturation [2]. Well log data are used to give erroneous values for water saturation and porosity in the presence of shale effect. The determinations of reservoir quality and formation evaluation processes are largely depend on quantitative evaluation of petrophysical analysis. Petrophysical analysis of gas reservoir of different gas field was carried out by Islam et al. [3-7] in Bengal Basin, Bangladesh. Rahman et al. [8] was carried out the analysis of reservoir sand of Titas-15 well using well log interpretation.

In this regard, the study was focused on the gas reservoir evaluation in the well Bakhrabad-09 of Meghna Gas Field, Bangladesh using wireline log interpretation. The objective of the study is to identify the gas zones of reservoir using composite log responses and to determine petrophysical parameters of the gas reservoir of the Meghna Gas Field, Bangladesh. It is located in Bancharampur upzila under Brahmanbaria District some $40 \mathrm{~km}$ away of northern most east direction from capital city of Dhaka, Bangladesh. Meghna Gas Field was discovered by BAPEX in 1990 [9] (Figure 1).

\section{Geologic Setting}

Bengal Basin is a productive gas-bearing basin in Southeast Asia. It is bounded by the Indian Shield on the west, north by the Precambrian Shillong Massif, on the east by the Arakan Yoma folded system and in the south it plunges into the Bay of Bengal (Figure 2). Foredeep part of the Bengal Basin is further subdivided into Eastern Chittagong-Tripura folded belt and unfolded western region deep basinal area also known as platform flank [10]. The Greater Bakhrabad structure lies on the southern fringes of the Surma Basin. The Surma Basin is the northeastern extension of the Bengal Fore deep [11]. Geologically, Morichakandi structure is situated in the western most part of the Chittagong-Tripura folded belt and a sub-structure of the Greater Bakhrabad, which lies on the north western part of the Bakhrabad (Figure 2). Titas Structure is present in the north and Kamta Structure lies in the west. Morichakandi structure is a symmetrical anticline with SE-NNE [12]. 


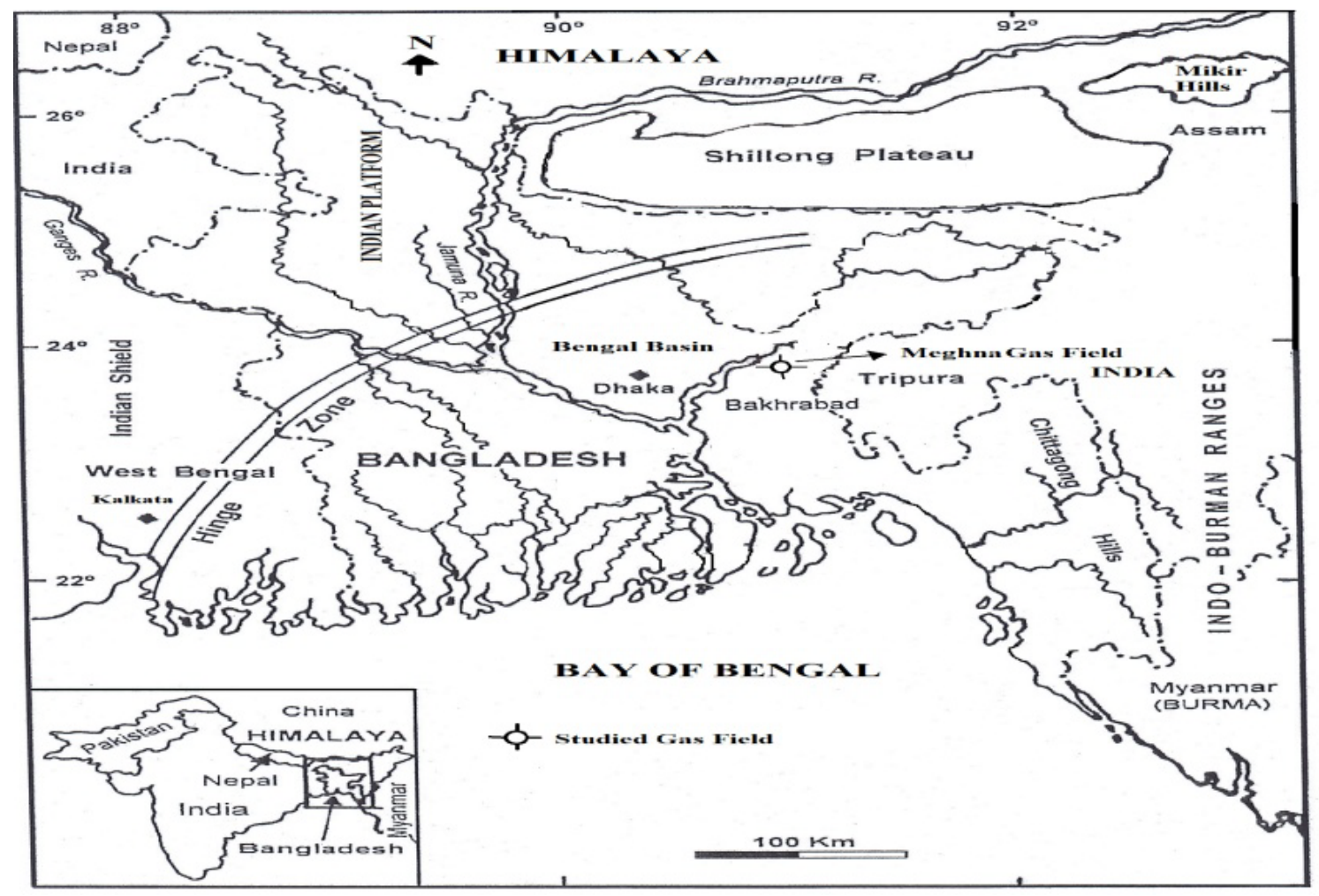

Figure 1. Map showing the location of the Meghna Gas Field (modified after Alam et at., [15])

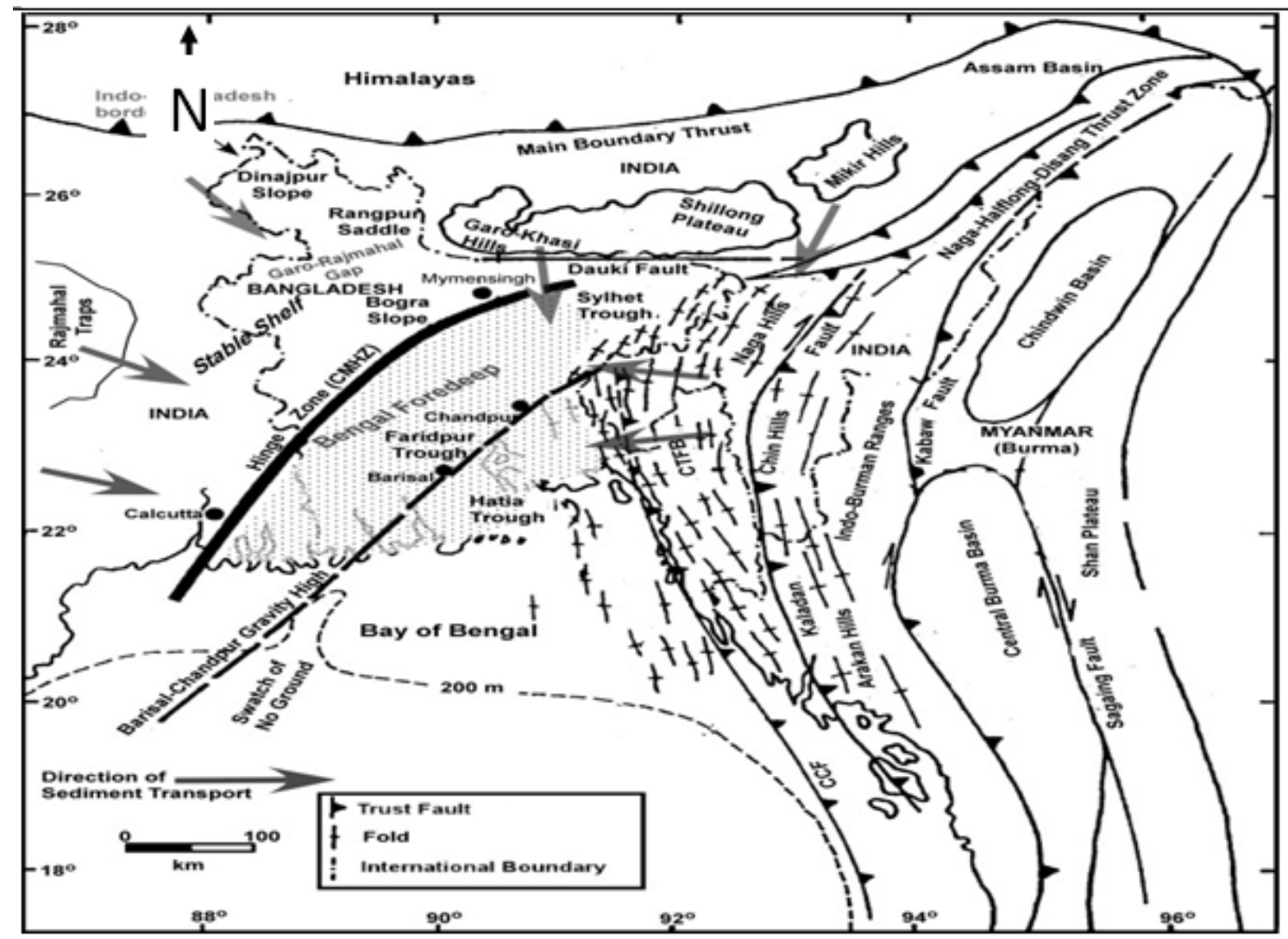

Figure 2. Regional map showing the tectonics elements of the Bengal Basin and surrounding areas (modified from [13-15] 


\section{Materials and Methods}

The wireline log from the well Bakhrabad-09 of the Meghna Gas Field was used for the study and data collected from Data Centre of the Bangladesh Petroleum Exploration and Production Company (BAPEX), Petrobangla. The wireline $\log$ includes resistivity logs (ILD and MSFL), density $\log$, neutron log, gamma ray (GR) log, self potential (SP) $\log$ etc. Description and evaluation of gas-bearing zones of the study well using wireline log. Digital data were analyzed by Excel software. Petrophysical parameters of the gas reservoir were determined by the following procedure:

At first step, the shale volume was calculated using Schlumberger equation [16]. Calculation of shale volume from gamma ray log using gamma ray index $\left(I_{G R}\right)$ for tertiary rocks [17].

$$
\begin{gathered}
I_{G R}=\frac{G R_{\log }-G R_{\min }}{G R_{\text {mix }}-G R_{\min }} \\
V_{s h}=0.083\left[2^{3.7 \times I_{G R}}-1.0\right]
\end{gathered}
$$

After computation of the volume of shale $\left(V_{s h}\right)$, computation of porosity and shale corrected from neutron-density logs. The following formula was proposed by Dresser Atlas [17] to calculate porosity from neutron and density logs:

$$
\begin{aligned}
& \emptyset_{\text {Den }}=\left(\frac{\rho_{m a}-\rho_{b}}{\rho_{m a}-\rho_{f}}\right)-V_{s h}\left(\frac{\rho_{m a}-\rho_{s h}}{\rho_{m a}-\rho_{f}}\right) \\
& \emptyset_{N c o r r}=\emptyset_{N}-\left[\left(\frac{\emptyset_{N c l}}{0.45}\right) \times 0.30 \times V_{s h}\right]
\end{aligned}
$$

Estimation of porosity ( $\varnothing$ ) was also calculated by Neutron-Density logs using Schlumberger [18].

$$
\begin{gathered}
\emptyset_{D \text { corr }}=\emptyset_{D-\left[\left(\frac{\emptyset_{N c l}}{0.45}\right) \times 0.13 \times V_{s h}\right]} \\
\emptyset_{\mathrm{N}^{-} \mathrm{D}}=\sqrt{\frac{\emptyset_{N \text { corr }} 2+\emptyset_{\text {Dcorr } 2}}{2.0}}
\end{gathered}
$$

Where, $\emptyset_{\mathrm{D}}=$ density porosity, $\emptyset_{N}=$ neutron porosity, $\rho_{m a}=$ matrix density (sandstone) $2.6 \mathrm{~g} / \mathrm{cm}^{3}, \rho_{b}=$ bulk density (log reading), $\rho_{f}=$ fluid density (for water $=1.0 \mathrm{~g} / \mathrm{m}$, for gas $=0.7 \mathrm{~g} / \mathrm{m}), \rho_{s h}=$ shale density.

After computation of porosity, the water saturation $\left(S_{w}\right)$ was calculated in the study. The following three formulas were commonly used to calculate water saturation of gas reservoir:

$$
\begin{aligned}
S_{w} & =\left(\frac{0.4 \times R_{w}}{\emptyset^{2}}\right)\left[\frac{V_{s h}}{R_{s h}} \sqrt{\left(\frac{V_{s h}}{R_{s h}}\right)^{2}+\frac{5 \emptyset^{2}}{R_{t} \times R_{w}}}\right] \\
S_{w} & =\frac{1}{\emptyset} \times\left[\sqrt{\frac{R_{w}}{R_{t}}+\left(\frac{a \times V_{s h}}{2}\right)^{2}-\frac{a \times V_{s h}}{2}}\right] \\
S_{w} & =\frac{\frac{V_{s h}}{R_{s h}}+\sqrt{\left(\frac{V_{s h}}{R_{s h}}\right)^{2}+\frac{\phi^{2}}{0.2 \times R_{w} \times\left(1.0-V_{s h}\right) \times R_{t}}}}{\frac{\phi^{2}}{0.4 \times R_{w} \times\left(1.0-V_{s h}\right) \times R_{t}}}
\end{aligned}
$$

Where, $S_{h}=$ Hydrocarbon saturation, $R_{s h}=$ Shale resistivity, $R_{w}=$ formation water resistivity, $R_{t}=$ true resistivity from the deep resistivity $\log , \mathrm{a}=1$ (tortusity factor) Equation (7), (8) and (9) were introduced by Simandoux [19], Fertl [20] and Schlumberger [21] respectively. Formation water resistivity $\left(R_{w}\right)$ was calculated by Bateman and Konen [22] equation.

$$
\begin{gathered}
\left.R_{w}=10^{\left\{\frac{S S P}{K}+\log R_{w}\right.}\right\} \\
S_{h}=1-S_{w}
\end{gathered}
$$

Determination of permeability $(\mathrm{K})$ was done by the following by Coates and Dumanoir [23] equation.

$$
\mathrm{k}=\left(\frac{c \times \emptyset^{2 w}}{W^{4} \times\left({ }^{R} w / R_{\text {tirr }}\right)}\right)^{2}
$$

$$
\text { Where, } \mathrm{W}=\left[\begin{array}{c}
\left.(3.75-\varphi)+\left\{\frac{\left[\log \left(\frac{R_{w}}{R_{\text {tirr }}}\right)+2.2\right]^{2}}{2}\right\}\right]^{1 / 2} \\
\mathrm{c}=23+465 \rho_{h}-188 \rho_{h}^{2}
\end{array}\right.
$$

Permeability was also calculated by using Wyllie and Rose [24] equation:

$$
\mathrm{K}=\left(79 \times \emptyset^{3} / S_{\text {wirr }}\right)^{2}
$$

Where, $S_{\text {wirr }}=$ saturation at irreducible water saturation, $R_{\text {tirr }}=$ deep resistivity at irreducible water resistivity, $\mathrm{SSP}=$ Static Self Potential, w and $\mathrm{c}=$ constant on hydrocarbon density, $\rho_{h}=$ hydrocarbon density ( 0.7 for gas)

Hydrocarbon moveability index is the ratio of the uninvaded zone and flushed zone and expression of the following Archie [25] equation:

$$
\frac{S_{w}}{S_{x o}}=\left[\frac{R_{x o} \times R_{w}}{R_{t} \times R_{m f}}\right]^{1 / 2}
$$

Where, $S_{x o}=$ flushed zone water saturation, $R_{m f}=$ mud filtrate resistivity, $R_{x o}=$ formation shallow resistivity.

The bulk volume of water (BVW) of the hydrocarbon-bearing zones in the studied well Bakhrabad-09 was computed using Moris and Biggs [26] equation:

$$
\mathrm{BVW}=S_{w} \times \emptyset
$$

\section{Results}

Petrophysical analysis determines different geometric properties of the reservoir such as lithology, shale volume, porosity, permeability, hydrocarbon saturation and bulk volume of water using available wireline logs. In the well Bakhrabad-09, 24 permeable zones were identified from the composite log responses (Table 1). Among these permeable zones, two zones were identified as hydrocarbon-bearing while remaining was water-bearing. 
Table 1. Permeable zones in the well Bakhrabad-09 of the Meghna Gas Field

\begin{tabular}{|c|c|c|c|}
\hline Zone No. & Zone Type & Depth Range (m) & Thickness (m) \\
\hline 1 & Water-bearing & $952-1004$ & 50 \\
\hline 2 & Water-bearing & $1006-1060$ & 54 \\
\hline 3 & Water-bearing & $1074-1097$ & 23 \\
\hline 4 & Water-bearing & $1304-1327$ & 23 \\
\hline 5 & Water-bearing & $1433-1454$ & 21 \\
\hline 6 & Water-bearing & $1524-1541$ & 17 \\
\hline 7 & Water-bearing & $1661-1690$ & 29 \\
\hline 8 & Water-bearing & $1765-1783$ & 18 \\
\hline 9 & Water-bearing & $1817-1847$ & 30 \\
\hline 10 & Water-bearing & $2054-2073$ & 19 \\
\hline 11 & Water-bearing & 2094-2131 & 37 \\
\hline 12 & Water-bearing & $2149-2191$ & 42 \\
\hline 13 & Water-bearing & $2191-2204$ & 13 \\
\hline 14 & Water-bearing & $2323-2353$ & 30 \\
\hline 15 & Water-bearing & $2398-2453$ & 55 \\
\hline 16 & Water-bearing & $2460-2478$ & 18 \\
\hline 17 & Water-bearing & $2560-2563$ & 3 \\
\hline 18 & Hydrocarbon-bearing & $2665-2676$ & 11 \\
\hline 19 & Water-bearing & $2753-2765$ & 10 \\
\hline 20 & Water-bearing & $2774-2792$ & 18 \\
\hline 21 & Water-bearing & $2837-2865$ & 21 \\
\hline 22 & Water-bearing & $2874-2890$ & 16 \\
\hline 23 & Hydrocarbon-bearing & $2935-2941$ & 6 \\
\hline 24 & Water-bearing & $2945-2955$ & 10 \\
\hline
\end{tabular}

Hydrocarbon-bearing zones in the well BaKhrabad-09 were identified with the help of SP, GR, resistivity, (ILD \& MSFL), neutron and density log responses. For this purpose, resistivity logs are the best option to detect gas-bearing zones. In these gas-bearing zones, gamma ray log shows low response and SP log shows high values as these deflects from shale base line. The resistivity log response in the gas-bearing zones is very high. Generally, gas-bearing zones deep resistivity log (ILD) value is higher than the shallow resistivity log (MSFL). Very low neutron and low density log responses support that hydrocarbon are gas type [27]. Composite log responses of the individual zones are shown in the figure 3 and 4.

Shale volume $\left(V_{s h}\right)$ is used to calculate the shale distribution in the reservoir. It also affects the water saturation in the study well. Shale volume was calculated by using Schlumberger equation [16]. The average shale volumes of these zones are $21 \%$ and $22 \%$ respectively which graphically presented in figure $5 \& 6$ and table 4 . The determination of porosity and permeability are a very important step for calculating fluid saturation in reservoir evaluation [28]. In this study, density and neutron log were only used for porosity determination. Permeability (K) was calculated by Coates and Dumanoir [23] and Wyllie and Rose [24] equation. Wyllie and Rose [24] equation was found better result for reservoir evaluation of the gas zones than Coates and Dumanoir equation. The calculate values of these zones are graphically presented in the figure $5 \& 6$ and table 2. Water saturation of the hydrocarbon-bearing zones has not calculated using Archie [25] equation because it is only valid for clean sandstone. The permeable zone with more than $60 \%$ hydrocarbon saturation is commonly treated as hydrocarbon-bearing [1]. The value of water saturation is less affected by incursion of shale and porosity. Three saturation equations were used to get more reliable saturation values. Three most used equations were proposed by Simondoux[19], Fertl [20] and Schlumberger [21] used for calculating water saturation as well as hydrocarbon saturation which graphically presented in the figure $5 \& 6$ and table 3. Simandaux [19] equation was found better suited for water saturation calculation than the equation of Fertl [20] and Schlumberger [21] in the zone-1. Schlumberger equation [21] was considered as a suitable for water saturation calculation and conversely for the calculation of hydrocarbon saturation than the equation of Simandoux [19] and Fertl [20] in the zone-2.

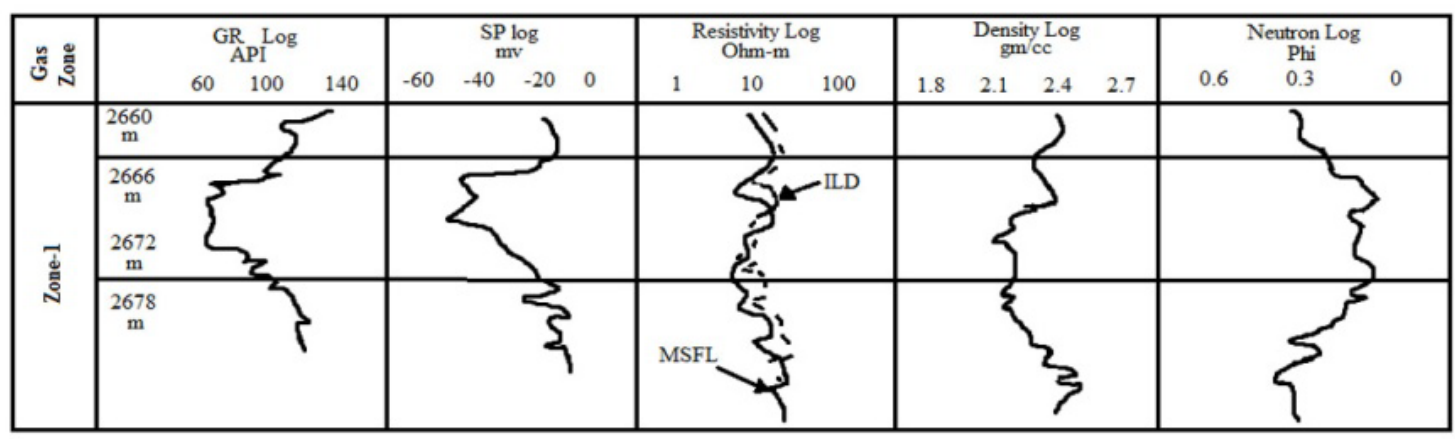

Figure 3. Composite log responses of the hydrocarbon bearing zone-1 in the the well Bakhrabad- 09 . 


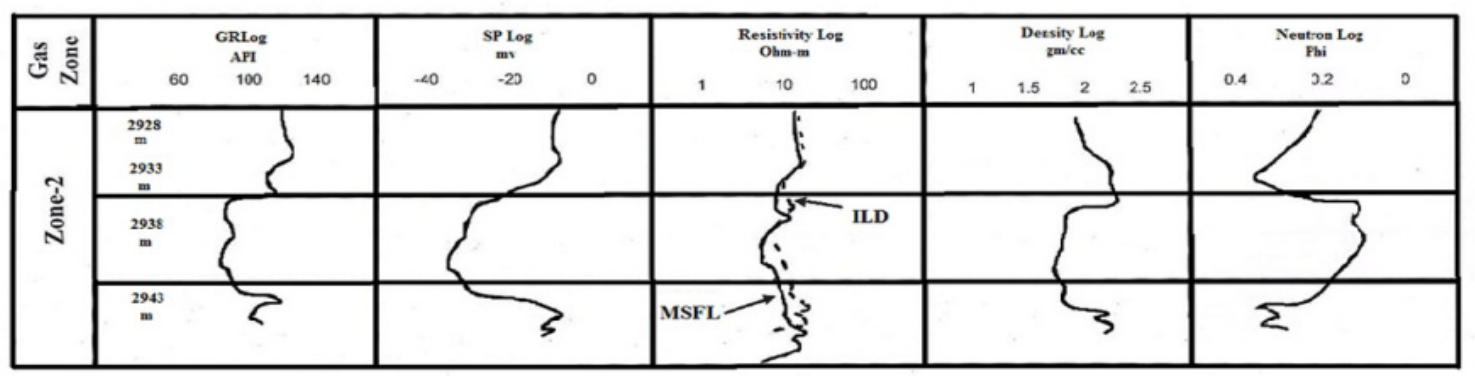

Figure 4. Composite log responses of the hydrocarbon bearing zone-2 in the well Bakhrabad-09.

Table 2. Distribution of permeability and porosity values of hydrocarbon-bearing zones in the well Bakhrabad-09.

\begin{tabular}{|c|c|c|c|c|c|c|c|c|}
\hline \multirow{2}{*}{ Zone No. } & $\begin{array}{c}\text { Depth Range } \\
(\mathrm{m})\end{array}$ & $\begin{array}{c}\text { Thickness } \\
(\mathrm{m})\end{array}$ & \multicolumn{4}{|c|}{ Permeability (Millidarcy) } & \multicolumn{2}{|c|}{$\begin{array}{c}\text { Porosity } \\
(\%)\end{array}$} \\
\cline { 4 - 9 } & & & \multicolumn{2}{|c|}{ Coates [23] } & \multicolumn{2}{|c|}{ Wyllie [24] } & \multicolumn{2}{|c|}{ Average } \\
\cline { 4 - 9 } & & & Range & Average & Range & Average & Range & 34 \\
\hline 1 & $2665-2676$ & 11 & $20-70$ & 45 & $20-90$ & 55 & $33-35$ & 31 \\
\hline 2 & $2935-2941$ & 6 & $16-60$ & 33 & $25-75$ & 50 & $23-28$ & 34 \\
\hline
\end{tabular}

Table 3. Distribution of hydrocarbon saturation values of gas-bearing zones in the well Bakhrabad-09.

\begin{tabular}{|c|c|c|c|c|c|c|c|c|}
\hline & & \multicolumn{5}{|c|}{ Hydrocarbon Saturation $\left(\mathrm{S}_{\mathrm{h}}\right) \%$} \\
\hline $\begin{array}{c}\text { Zone } \\
\text { No. }\end{array}$ & $\begin{array}{c}\text { Depth Range } \\
(\mathrm{m})\end{array}$ & $\begin{array}{c}\text { Thickness } \\
(\mathrm{m})\end{array}$ & \multicolumn{2}{|c|}{$\mathrm{S}_{\mathrm{h}}$ Simandoux [19] } & \multicolumn{2}{|c|}{$\mathrm{S}_{\mathrm{h}}$ Fertl [20] } & \multicolumn{2}{c|}{$\mathrm{S}_{\mathrm{h}}$ Schlumberger [21] } \\
\hline & & & Range & Average & Range & Average & Range & Average \\
\hline 1 & $2665-2676$ & 11 & $70-75$ & 73 & $65-70$ & 66 & $67-77$ & 71 \\
\hline 2 & $2935-2941$ & 6 & $60-65$ & 62 & $80-85$ & 82 & $86-88$ & 87 \\
\hline
\end{tabular}

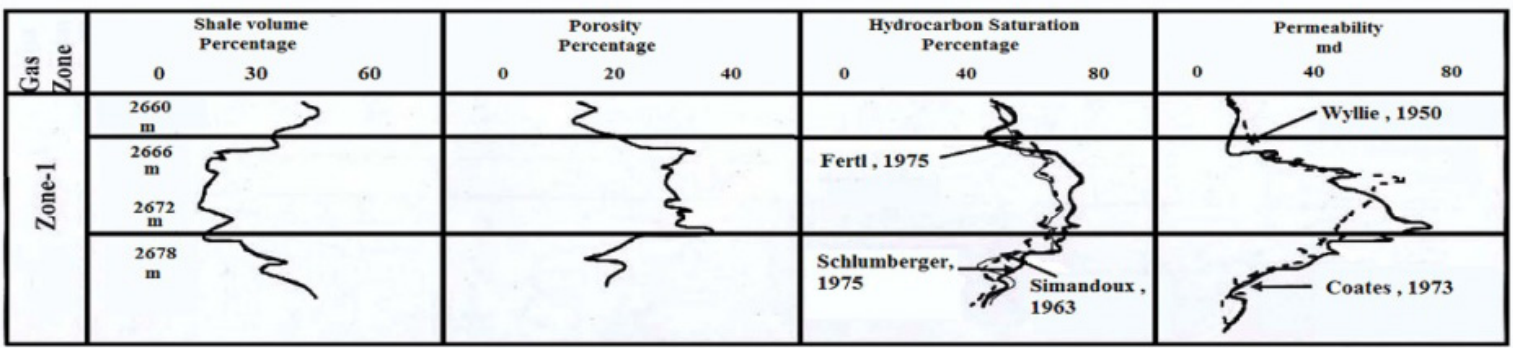

Figure 5. Graphical representation of petrophysical parameters (Shale volume, Porosity, Hydrocarbon distribution and Permeability) of the hydrocarbon bearing zone-1 in the well Bakhrabad-09.

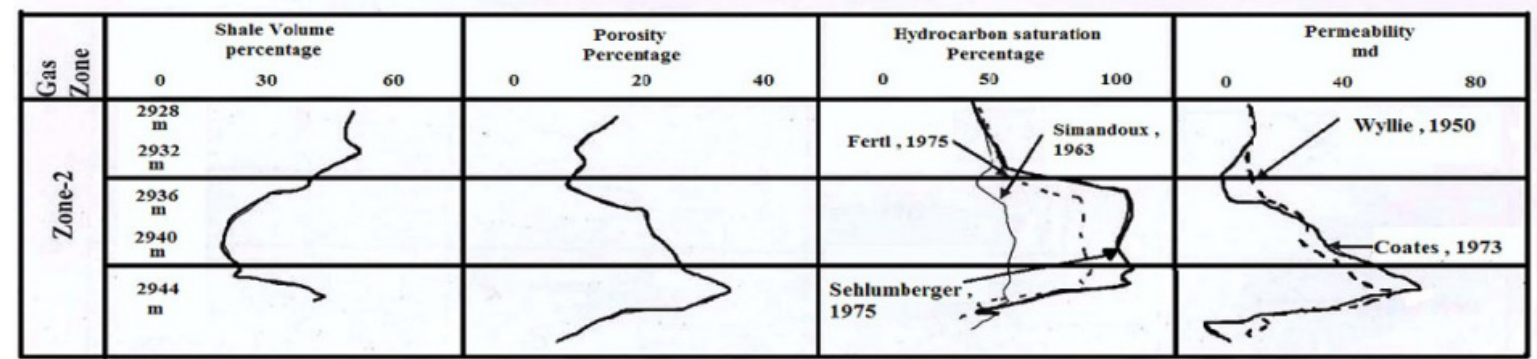

Figure 6. Graphical representation of petrophysical parameters (Shale volume, Porosity, Hydrocarbon distribution and Permeability) of the hydrocarbon bearing zone-2 in the well Bakhrabad-09 
Table 4. Distribution of hydrocarbon moveability index, BVW and volume of shale values in the hydrocarbon-bearing zones in the well Bakhrabad-09.

\begin{tabular}{|c|c|c|c|c|c|c|c|c|}
\hline \multirow{3}{*}{$\begin{array}{c}\text { Zone } \\
\text { no. }\end{array}$} & \multirow{3}{*}{$\begin{array}{l}\text { Depth } \\
\text { ranges(m) }\end{array}$} & \multirow{3}{*}{$\begin{array}{l}\text { Thickness } \\
\text { (m) }\end{array}$} & \multirow{2}{*}{\multicolumn{2}{|c|}{$\begin{array}{l}\text { Hydrocarbon Moveability } \\
\text { Index }\left(\boldsymbol{S}_{\boldsymbol{w}} / \boldsymbol{S}_{\boldsymbol{x} \boldsymbol{o}}\right)\end{array}$}} & \multicolumn{2}{|c|}{$\begin{array}{l}\text { Bulk Volume of Water } \\
\text { (BVW) }\end{array}$} & \multicolumn{2}{|c|}{ Volume of Shale (\%) } \\
\hline & & & & & \multirow{2}{*}{ Range } & \multirow{2}{*}{ Average } & \multirow{2}{*}{ Ranges } & \multirow{2}{*}{ Average } \\
\hline & & & Range & Average & & & & \\
\hline 1 & $2665-2676$ & 11 & $0.14-0.27$ & 0.19 & $0.052-0.055$ & 0.053 & $12-30$ & 21 \\
\hline 2 & 2935-2941 & 6 & $0.11-0.55$ & 0.29 & $0.04-0.049$ & 0.045 & $10-34$ & 22 \\
\hline
\end{tabular}

Hydrocarbon moveability index is the ratio between water saturation of uninvaded zone $\left(S_{w}\right)$ to the water saturation of flushed zone $\left(S_{x o}\right)$. If the ratio of $S_{w}$ and $S_{x o}$ is equal to or greater than 1.0, then hydrocarbon will not move within the well. If the saturation index is less than 0.7 (for sandstone), hydrocarbon is moveable [29]. Hydrocarbons are moveable in the study well because all the calculated values are less than 0.7. It is important to know that BVW whether the formation is at irreducible water saturation or not using Morris and Biggs [26] equation. If The BVW ranges from 0.035 to 0.07 , the grain size is fine to very fine-grained sand [30]. Bulk volume of water is nearly constant with some minor scattering in the hydrocarbon-bearing zones which indicate that the water free hydrocarbon (Table 4).

\section{Discussions}

The quantitative analysis of wireline log data gives the clue that whether the well would be commercially viable or not. In well Bakhrabad-09, two hydrocarbon-bearing zones were identified with depth ranges of 2665-2676 $\mathrm{m}$ and 2945-2955 $\mathrm{m}$ having average thickness of $11 \mathrm{~m}$ and $6 \mathrm{~m}$. (Table 1). GR log value of these zones were average 60 API indicate the value below it were shown to be gas sand reservoir while the value above it were shown to be shale. SP log values were average $-40 \mathrm{mv}$ indicate gas sand reservoir. The true resistivity $\left(R_{t}\right)$ values of these zones were greater than the water bearing resistivity $\left(R_{0}\right)$ value [31]. The average true resistivity ranged from 10 to $50 \Omega$ m suggest gas reservoir with higher average true resistivity values have lower water bearing resistivity and vice versa. The density and neutron log value of these zones were average 1.95 $\mathrm{g} / \mathrm{cm}^{3}$ and 0.15 phi respectively. Both the density and neutron log responses through gas reservoir support that hydrocarbon types are gas (Figure 3 and 4).

The average shale volume of these zones were ranged from $21-22 \%$ which converted to sand volume $81-82 \%$ support that gas reservoir consist of shaly sand dominating lithology (Table 4). The average shale values in the well Bakhrabad-09 are relatively low sufficient to allow for free fluid flow of hydrocarbon. The average shale volumes are within the ranges $(21 \%)$ which show that less affects the water saturation values in the reservoir (Figure 5 and 6). It indicates that the reservoir is evidence of sand development
[32]. The average log derived porosity values of these zones ranges from $31 \%$ to $34 \%$ which indicates very good porosity in the gas reservoir. Similar observation of porosity value was made by Ajisafe [33] in "Y" Field Niger Delta. The average permeability of these zones ranges from 42.5 md to $50 \mathrm{md}$ shows good enough to accumulate hydrocarbon. The average porosity/permeability values $33 \% / 45 \mathrm{md}$ are good average to permit free fluid flow of hydrocarbon in the gas reservoir (Table 2 and figure $5 \& 6$ ). The average hydrocarbon saturation values of the two gas zones were $68 \%$ by using Simandoux [19], $74 \%$ following by Fertl [20] and $79 \%$ following by Schlumberger equation [21] (Figure 5 \& 6 and table 3). Higher average hydrocarbon saturation values suggest that gas reservoir is built up very high hydrocarbon accumulation. Same observation was made elsewhere in Bengal Basin by Islam et al. [4] [7]. Average hydrocarbon moveability index of the zones ranges form $0.19-0.29$ indicate that hydrocarbon is moveable in the study well. Bulk volume of water values are average ranges from 0.045-0.053 suggests gas reservoir consist of mainly fine to very fine grained sandstone (Table 4). Islam et al. [5-6] made also similar result in Kailas Tila and Shahbazpur Gas Field of the Bengal Basin.

\section{Conclusions}

The reservoir quality of the well Bakhrabad-09 was studied using wireline log interpretation. Out of 24 permeable zones, two gas-bearing zones were identified in the study well on the basis of available composite log responses. The comparatively high resistivity $\log , \log$ GR log, high SP log, very low neutron and low density log responses indicate that hydrocarbon might be gas-bearing. The mean shale volumes of those zones are low values show that shaly sand dominating lithology and less affect the water saturation values in the gas reservoir. The porosity value ranges between $23 \%-38 \%$ indicate good porosity of the reservoir. The permeability value ranges between 33 md- 55 md show that potential reservoir for hydrocarbon accumulation. The average water saturation value ranges between $13 \%$-38 \% which convert to average gas saturation value ranges between $62 \%-87 \%$ indicate very high hydrocarbon accumulation. Bulk volumes of water (BVW) of these zones ranges between $0.04-0.055$ reveal that fine to 
very fine grain sandstone develop in the gas reservoir. Hydrocarbon is moveable which support by the calculated values in the study well. It suggests that the gas reservoir in the well Bakhrabad-09 have very good qualities with average $33 \%$ porosity, average $21 \%$ shale volume, hydrocarbon saturation values as high as more than $60 \%$ and average permeability $46 \mathrm{md}$. The study also suggests that the gas-bearing zones of the reservoirs are prospective for commercial hydrocarbon accumulation and production.

\section{Acknowledgements}

The authors are highly grateful to the Chairman of Bangladesh Oil, Gas and Mineral Corporation (Petrobangla) and the Managing Director, BAPEX for their required approval and kind permission to provide necessary data and facilities while conducting this research.Thanks are due to anonymous reviewer who made a constructive review.

\section{REFERENCES}

[1] G.B. Asquith and C.R. Gibson. Basic well log analysis for geologist; Text book, AAPG, Tulsa, Okalhoma, U.S.A, 1982.

[2] S.Sakura. Petrophysical evaluation of Miocene-Pliocene gas reservoir:Veracruz and Macuspana Basin, Mexico. SPWLA $43^{\text {rd }}$ Annual Logging Symposium, 1-13, 2002.

[3] M.M. Nawab and M.A. Islam. Estimation of shale volume using gamma and porosity logs: Application to the selected Gas Field of Bangladesh; Bangladesh Geoscience Journal, v.11,pp.89-99, 2005

[4] Islam, M.A., Islam, M.S.,Latif, M.H., Mondal, D. and M.A. Mahbub. Petrophysical analysis of shaly-sand gas reservoir of Titas Gas Field using well logs, Bangladesh, Journal of Geology, v.25, p.106-124, 2006.

[5] M.A. Islam, M.S. Islam, D. Mondol. Log derived shaly-sand analysis of Shahbazpur Gas Field, Bhola, Bangladesh; Bangladesh Geoscience Journal, v.13, pp.63-77, 2007.

[6] M. A. Islam, M.S. Islam,S. Talukder,K.E. Haque, M.A. Rahman, F. Ahmed. Petrophysical evaluation of Neogene Shaly-sand gas reservoir: A case study of Kailas Tila Gas Field; Bengal Basin, Bangladesh, International Journal of Earth Science and Engineering, v.2, pp.499-511, 2009.

[7] M.A. Islam. Petrophysical evaluation of subsurface reservoir sandstone of Bengal Basin,Bangladesh, Journal Geo Science of India, v.76, pp.621-631, 2010 .

[8] M.M. Rahman, A.S.M . Woobaidullah, B.Imam and M.M.Rahman. Evaluation of Reservoir Sands of Titas-15 Well by Wireline log interpretation; Bangladesh Geoscience Journal, v.15, p.67-75, 2009

[9] Bangladesh Petroleum Exploration Production Company (BAPEX). Interpretation Report on the greater Bakhrabad Structure; Data Centre, Petrobangla, Dhaka, 1990.

[10] A.H.M. Shamsuddin and S.K.M. Abdullah. Geological
Evaluation of the Bengal Basin and its implication in hydrocarbon exploration in Bangladesh; Indian Journal of Geology, v.69 (2), pp.93-121, 1997.

[11] K.U., Reimann. Geology of Bangladesh, Gebruder Barntrager, Berlin, Stuttgart, Germany, p.160, 1993.

[12] Bangladesh Oil, Gas, Mineral and Corporation (BOGMC). Well Completion Report, Bakhrabad \#09, Geological Evaluation Division. Petrobangla, Dhaka, 1991.

[13] S.Y. Johnson, and A.M.N. Alam. Sedimentation and Tectonics of the Sylhet Trough, Bangladesh; Geological Society of America. Bulletin, v.103, pp.1513-1527, 1991.

[14] A. Uddin and N. Lindberg. Miocene paleogeography of the Bengal Basin, Bangladesh: Sub-surface lithofacies analysis; Abstracts American Geophysics Union, Spring Meeting, p. 52-79, 1995.

[15] M.M., Alam, J.R. Curray, M.L.R. Chowdhury, \& M.R. Gani. An overview of the sedimentary geology of the Bengal Basin in relation to the regional tectonic framework and basinfill history; Sedimentary Geology, v.155, pp.179-208,2003.

[16] Schlumberger. Log Interpreation.Volume-I-Principles; Houston, Schlumberger Well Services Inc., 1972.

[17] Dresser Atlas. Log Interpretation Charts; Houston, Dresser Industries. Inc., p.107, 1979.

[18] Schlumberger. Log interpretation, volume-II-principles; Houston, Well Services Inc., 1974.

[19] P. Simandoux. "Mesures dielectriques en milieu poreux, application a mesure des saturations en eau, Etude du Comportment des massifs Argileux"; Revue de I'Institut Francais du Petrol, Supplementary Issue, 1963.

[20] W.H. Fertl. Shaly-sand analysis in development wells; Soc. Professional Well Log Analysis, 16 ${ }^{\text {th }}$ Ann Logging Symp. Trans., Paper A, 1975.

[21] Schlumberger. A Guide to wellsite interpretation of the Gulf Coast: Houston, Schlumberger Well Services, Inc, 1975.

[22] [24] R.M. Bateman, and C.E., Konen. The log analyst and the programmable pocket calculator; the log Analyst. v.18 (5), p.3-11, 1977.

[23] G. Coates, and J. L. Dumanoir. A new approach to improve log-derived permeability; Society of Professional Well Log Analysis, 14 ${ }^{\text {th }}$ Ann. Logging Symp., Trans., Paper R, 1973.

[24] M.R.J .Wyllie and W.D. Rose. Some theoretical considerations related to the quantitative evaluations of the physical characteristics of reservoir rock from electric log data: Journal. Petroleum Technology, v.189. p. 105-110, 1950 .

[25] G.E. Archie. The Electrical Resistivity Log as an aid in determining some reservoir characteristics. Petroleum Technology v.5, pp.54-62, 1942.

[26] R.L. Morris, and W.P. Biggs. Using log-derived values of water saturation and porosity; Society Professional Well Log Analysis, $8^{\text {th }}$ Ann. Logg. Symp. Trans. Paper O., 1967.

[27] G. Asquith and D. Krygowski. Basic Log Analysis, AAPG methods in exploration series, v. 16, pp.204, 2004. 
[28] N. Ruhovets. A $\log$ analysis technique for evaluating laminated reservoir in the Gulf Coast. The log analyst, v.3, pp. 294-303, 1990.

[29] Schlumberger. Log interpretation charts, English metric, Schlumberger publication, 1979.

[30] W.H. Fertl, and W.C. Vercellino. Predict water cut from well logs, in practical log analysis-4: Oil and Gas Journal. (May 15, 1978).

[31] A.T. Hingle. The use of logs in exploration problems; Society of Exploration Geophysics, $29^{\text {th }}$ conference meeting, 1959.

[32] M.O. Eze, A.W. Mode and C.C. Ugbor. Formation evaluation of X7 field in the Niger Delta: evidence from Petrophysical data. Niger Delta, Nigeria, IOSR Jour. of Appl. Geo. and Geoph., v.1 (4), pp.15-21, 2013.

[33] Y.C. Ajisafe and B.D. Ako. 3-D seismic attributes for reservoir characterization of "Y" field Niger Delta, Nigeria, IOSR Jour. of Appl. Geo. and Geoph., v.1 (2), pp.23-31, 2013. Doi 10.9790/0990-0122331. 